archives-ouvertes

\title{
Aldosterone receptor antagonists
}

Michel Azizi, Hypertension Récepteurs

\section{To cite this version:}

Michel Azizi, Hypertension Récepteurs. Aldosterone receptor antagonists. Annales d'Endocrinologie, Elsevier Masson, 2020, 10.1016/j.ando.2020.03.009 . hal-03111198

\section{HAL Id: hal-03111198 \\ https://hal.archives-ouvertes.fr/hal-03111198}

Submitted on 22 Jan 2021

HAL is a multi-disciplinary open access archive for the deposit and dissemination of scientific research documents, whether they are published or not. The documents may come from teaching and research institutions in France or abroad, or from public or private research centers.
L'archive ouverte pluridisciplinaire HAL, est destinée au dépôt et à la diffusion de documents scientifiques de niveau recherche, publiés ou non, émanant des établissements d'enseignement et de recherche français ou étrangers, des laboratoires publics ou privés. 
Klotz communication 2020: Heart and Hormones

\title{
Aldosterone receptor antagonists
}

\section{Antagonistes du récepteur de l'aldostérone}

\author{
Michel Azizi \\ Inserm CIC1418, service d'hypertension artérielle et DMU CARTE, HEGP, université de Paris, AP-HP, 20-40, rue Leblanc, 75015 Paris, France
}

\section{A R T I C L E I N F O}

\section{Keywords:}

Hypertension

Aldosterone

Receptors

\begin{abstract}
A B S T R A C T
Blocking the mineralocorticoid receptor (MR) is one of the most effective ways of reducing blood pressure in patients with resistant hypertension and improving cardiovascular prognosis in patients with heart failure with reduced ejection fraction and left ventricular dysfunction after myocardial infarction. Blockade of the biological effects of aldosterone has mostly been achieved with spironolactone and eplerenone, the two steroidal MR antagonists currently on the market. Development of new non-steroidal dihydropyridine-based third- and fourth-generation MR antagonists is ongoing. These antagonists are highly selective for the MR, but have no effect on the glucocorticoid, androgen, progesterone and estrogen receptors, in contrast with spironolactone.
\end{abstract}

\section{R É S U M É}

Le blocage des récepteurs minéralocorticoïdes (RM) est l'un des moyens les plus efficaces de réduire la pression artérielle chez les patients ayant une hypertension artérielle résistante et pour améliorer le pronostic cardiovasculaire chez les patients ayant une insuffisance cardiaque avec une fraction d'éjection réduite et un dysfonctionnement ventriculaire gauche après un infarctus du myocarde. Le blocage des effets biologiques de l'aldostérone est réalisé par la spironolactone et l'éplérénone, deux antagonistes stéroïdiens du RM actuellement sur le marché. Le développement de nouveaux antagonistes du RM de troisième et quatrième génération non stéroïdiens est en cours. Ces antagonistes sont hautement sélectifs pour le RM, mais n'ont aucun effet sur les récepteurs des glucocorticoïdes, des androgènes, de la progestérone et des œstrogènes, contrairement à la spironolactone.

\section{Introduction}

The biological effects of aldosterone on the renal excretion of sodium and potassium and blood pressure (BP) regulation extend far beyond extracellular volume regulation and potassium homeostasis. Independently of its renal effects [2], aldosterone, together with high sodium intake, stimulates inflammatory reactions, cellular hypertrophy, matrix formation and apoptosis in the vessels, heart and kidneys [3]. It is also directly involved in target organ damage in various cardiovascular and renal diseases [3]. Finally, a relative aldosterone excess is frequently observed in patients with resistant hypertension [4].

\footnotetext{
E-mail address: michel.azizi@aphp.fr
}

Blockade of the biological effects of aldosterone has mostly been achieved with the two mineralocorticoid receptor antagonists (MRAs) currently on the market, spironolactone and eplerenone. MRAs competitively bind to the mineralocorticoid receptor (MR) and block its activation by aldosterone and other mineralocorticoids [1]. Spironolactone and eplerenone are used as potassium-sparing diuretics and antihypertensive agents in various conditions with primary aldosteronism (PA) or secondary hyperaldosteronism. Blocking the mineralocorticoid receptor (MR) is one of the most effective ways of reducing BP in patients with resistant hypertension [5-7] and improving cardiovascular prognosis in patients with heart failure with reduced ejection fraction (HFrEF) and left ventricular dysfunction after myocardial infarction(MI) [8].

This review will focus on the use of MRAs in resistant hypertension. 
G Model

ANDO-1168; No. of Pages 3

\section{Spironolactone}

Spironolactone is a steroidal MRA approved in 1959 and is available worldwide. It is rapidly metabolized by the liver into various metabolites, including canrenone, which have antimineralocorticoid activities and longer half-lives that the parent drug. Spironolactone has been given once daily at doses ranging from 1 to $4 \mathrm{mg} / \mathrm{kg}$ in patients with primary hypertension or with PA, but there is little evidence that doses $>50 \mathrm{mg}$ /day lead to a greater reduction in BP [1,9]. However, several factors may limit the use of MR antagonists. Firstly, spironolactone has a poor tolerance profile because of its lack of selectivity for the MR $[1,9]$. It also binds to the progesterone and androgen receptors, thereby triggering progestogenic and antiandrogenic effects [1]. Its long-term use is therefore associated with a dose-related incidence of gynecomastia in males, sexual dysfunction and menstrual irregularities in females, which may occur at any time during the course of treatment, with incidence of $6.9 \%$ at doses of $50 \mathrm{mg}$ /day or less and exceeding $50 \%$ at doses of $150 \mathrm{mg} /$ day or more, and may be reversed by stopping treatment [10].

\section{Eplerenone}

Eplerenone is a steroidal MRA that is more selective for the MR than spironolactone [1], and does not interfere with progesterone or androgen receptors. It is marketed to improve the survival of stable patients with left ventricular systolic dysfunction and clinical evidence of congestive heart failure after acute MI [8]. It is also used as an alternative to spironolactone in patients with essential hypertension or PA [9], but is not approved everywhere worldwide in these indications. Eplerenone differs from spironolactone in that its affinity for the progesterone and androgen receptors is 500-fold lower and it does not, therefore, have the sexual side effects of spironolactone $[1,10]$. No active metabolites have been identified, and its elimination half-life $(4-6 \mathrm{~h})$ is shorter [1,9]. Eplerenone is a short-acting steroidal MRA that is less potent than spironolactone on a milligram-to-milligram basis [10]. It is given at doses of $25-50 \mathrm{mg} /$ day to patients with cardiac failure [8], and at doses of $50-100 \mathrm{mg}$ once or twice daily to patients with primary hypertension [9]. It has been tested in patients with PA at doses from 50 to $300 \mathrm{mg} /$ day [11].

\section{The use of MRAs in resistant hypertension}

According to the 2018 European guidelines [6], hypertension is defined as resistant to treatment when the recommended treatment strategy fails to bring systolic (SBP) and diastolic blood pressure (DBP) values to below $140 \mathrm{mmHg}$ and/or $90 \mathrm{mmHg}$, respectively, and the inadequate control of $\mathrm{BP}$ is confirmed by ambulatory BP monitoring or home BP monitoring in patients whose adherence to therapy has been confirmed. The recommended treatment strategy (Class I A recommendation) should include appropriate lifestyle measures and treatment with optimal or best-tolerated doses of three or more drugs that should include a diuretic and typically an ACE inhibitor or angiotensin receptor blocker (ARB), and a long-acting calcium channel blocker (CCB). A meta-analysis of 20 observational studies and randomized controlled trials estimated the prevalence of resistant hypertension (RHTN) at $13.7 \%$ (95\% confidence interval (CI): 11.2\%-16.22\%) for observational studies and $16.3 \%$ (95\% CI: 10.7\%-21.9\%) for randomized controlled trials [12]. RHTN is associated with a higher prevalence of end-organ damage than well-controlled hypertension, including left ventricular hypertrophy, carotid intima-media thickening, microalbuminuria and retinal lesions [6,13,14]. The frequent association of target organ damage and the clustering of cardiovascular risk factors in patients with RHTN accounts for the higher risk of a major cardiovascular event in these patients and, thus, of poor short-term prognosis [6,15].

Multidrug drug regimens are required to achieve BP goals through interference with the complex interplay of different pathways implicated in the pathogenesis of RHTN, which, by contributing to volume and sodium overload, increases arterial stiffness, and renal fibrosis in the mid- and long-term. Other factors, including age, ethnicity, the presence of associated comorbid conditions, chronic kidney disease and proteinuria, compelling indications for certain classes of drugs, and the risk of drug-drug interactions, should be taken into account for the treatment [6].

Reduction of sodium and alcohol intake, as well as weight reduction and regular exercise should always be part of the treatment approach $[6,16,17]$. For those with obstructive sleep apnea, continuous positive airway pressure (CPAP) may be of moderate benefit, [18] but this remains a matter of debate for patients with RHTN, and long-term compliance with CPAP may be problematic. In addition, effective treatment combines discontinuation of interfering substances, and the sequential addition of antihypertensive drugs to the initial triple therapy. Ultimately, all current drugs should be replaced by a simpler treatment regimen using single pill combination therapy to reduce pill burden and improve adherence to treatment [6].

The first step of RHTN care is to optimize the doses of current treatment or to prescribe appropriate antihypertensive drug combinations [6]. One of the causes of RHTN is inappropriate refractory volume retention of multifactorial origin, as suggested by the low renin levels measured in patients with RHTN [19]. BP control can thus be improved by increasing the intensity of diuretic therapy, particularly in patients with chronic kidney disease [16]. The dose of the diuretic can be increased or a more potent thiazide-like diuretic (indapamide and chlorthalidone) can be used instead of hydrochlorothiazide or bendroflumethiazide if eGFR $\geq 30 \mathrm{ml} / \mathrm{min}$ [6]. Loop diuretics should be used when eGFR $<30 \mathrm{ml} / \mathrm{min}$ [6], although small studies reported that thiazides may retain their natriuretic and antihypertensive effects when eGFR $<30 \mathrm{ml} / \mathrm{min}$.

The fourth-line treatment should involve an MRA, such as spironolactone (Class I A recommendation) [6]. MR blockade is an effective way to decrease BP in patients with RHTN for multiple pathophysiological reasons, [20] as shown in randomized trials and meta-analyses [21]. The PATHWAY-2 double-blind crossover study has provided the strongest evidence in favor of the use of spironolactone as a fourth-line treatment added to a pre-existing three-drug regimen (an ACEI, a CCB, and a low dose of bendroflumethiazide) in overweight patients with RHTN, eGFR $\geq 45 \mathrm{ml} / \mathrm{min}$, and plasma potassium concentrations within the normal range [5]. Indeed, 12-week treatment with spironolactone $25-50 \mathrm{mg}$ was the most effective treatment, allowing BP control in $58 \%$ of the patients compared to $42 \%$ of those treated with doxazosin (4-8 mg), and $43 \%$ of those treated with bisoprolol (5-10 mg). However, both bisoprolol and doxazosin reduced BP more than placebo when added to background treatment. Spironolactone was more effective in those with a low renin profile on the initial triple combination therapy. The risk of hyperkalemia may be greater in patients with chronic kidney disease, particularly if spironolactone is added to a treatment including a RAS blocker, making it necessary to monitor plasma potassium and creatinine concentrations closely. The efficacy and safety of spironolactone has not yet been established in patients with significant renal insufficiency.

Amiloride ( $10 \mathrm{mg}$ once daily) was later shown to achieve a BP decrease comparable to spironolactone $25 \mathrm{mg}$ once daily [22]. Finally, the ReHOT (Resistant Hypertension Optimal Treatment) randomized study [23] comparing 12-week treatment with spironolactone (12.5-50 mg QD) or clonidine (0.1-0.3 mg BID) in Brazilian patients, showed similar rates of combined office and 
24-hour ambulatory BP control [23]. The rate of side effects reported for both spironolactone and clonidine was low. The patients randomized to clonidine more frequently had somnolence.

Specialist advice should be sought at a dedicated tertiary BP clinic if BP still remains uncontrolled [6]. At this stage, stepwise addition of a beta-blocker (with the exception of atenolol), an alpha-blocker, and a centrally acting alpha-agonist is preferred. The complexity of the multidrug therapeutic regimens used in patients with RHTN increases the likelihood of drug-related side effects and may contribute to the lack of adherence to treatment by patients who may be taking large numbers of other drugs for comorbid conditions.

\section{Non-steroidal dihydropyridine-based mineralocorticoid receptor antagonists}

Development of new non-steroidal dihydropyridine-based third- and fourth- generation MRA is ongoing. The first-in-class of this new generation of MRAs is dihydronaphthyridine finerenone. [1] Finerenone is a passive antagonist highly selective for the MR, but has no effect on the glucocorticoid, androgen, progesterone and estrogen receptors [1]. Its in vitro potency toward the MR is similar to that of spironolactone [1]. Finerenone was initially developed for the treatment of heart failure with reduced ejection fraction (HFrEF) [24] but, despite initial encouraging results, it was not developed further for the treatment of HF. Finerenone is currently investigated for the prevention of renal and cardiovascular complications in patients with diabetic nephropathy (FIDELIO-DKD, NCT02540993 and FIGARO-DKD, NCT02545049). Two other nonsteroidal MRAs, esaxerenone and apararenone, are being developed in Japan for the treatment of hypertension and diabetic nephropathy [1]. However, it should be borne in mind that the risk of adverse events associated with non- steroidal MRAs is probably similar to that for the first generation of steroidal MRAs, and may include electrolyte disorders, hypotension, renal insufficiency and severe hypoaldosteronism, depending on residual aldosterone production, initial renal function, dehydration, general anesthesia, comorbidities (type-2 diabetes), and coprescriptions (COX inhibitors, RAS blockers, heparin, trimethoprim-sulfamethoxazole etc.) [25].

In summary, RHTN is commonly a salt-retaining state, most likely due to inappropriate aldosterone secretion [22]. MR blockade by spironolactone overcomes the salt retention and resistance of hypertension to treatment. Spironolactone ( 25 to $50 \mathrm{mg} /$ day) should be used in patients with RHTN but restricted to those with an $e G F R \geq 45 \mathrm{ml} / \mathrm{min}$ and plasma potassium concentration $\leq 4.5 \mathrm{mmol} / \mathrm{L}$, particularly in cases of a compelling indication, such as heart failure, in accordance with guidelines [6]. When spironolactone is contraindicated or not tolerated, bisoprolol, [5] doxazosin, [5] amiloride [22] or clonidine [23] can be used for the treatment of RHTN.

\section{Disclosure of interest}

The author declares that he has no competing interest.

\section{References}

[1] Kolkhof P, Barfacker L. 30 years of the mineralocorticoid receptor: mineralocorticoid receptor antagonists: 60 years of research and development. J Endocrinol 2017;234:T125-40.
[2] Funder JW, Mihailidou AS. Aldosterone and mineralocorticoid receptors: clinical studies and basic biology. Mol Cell Endocrinol 2009;301:2-6.

[3] Brown NJ. Aldosterone and end-organ damage. Curr Opin Nephrol Hypertens $2005 ; 14: 235-41$.

[4] Gaddam KK, Nishizaka MK, Pratt-Ubunama MN, Pimenta E, Aban I, Oparil S, et al. Characterization of resistant hypertension: association between resistant hypertension, aldosterone, and persistent intravascular volume expansion. Arch Intern Med 2008;168:1159-64.

[5] Williams B, MacDonald TM, Morant S, Webb DJ, Sever P, McInnes G, et al. Spironolactone versus placebo, bisoprolol, and doxazosin to determine the optimal treatment for drug-resistant hypertension (pathway-2): A randomised, double-blind, crossover trial. Lancet 2015;386:2059-68.

[6] Williams B, Mancia G, Spiering W, Agabiti Rosei E, Azizi M, Burnier M, et al. 2018 esc/esh guidelines for the management of arterial hypertension. Eur Heart J 2018;39:3021-104.

[7] Carey RM, Calhoun DA, Bakris GL, Brook RD, Daugherty SL, DennisonHimmelfarb CR, et al. Resistant hypertension: Detection, evaluation, and management: A scientific statement from the american heart association. Hypertension 2018;72:e53-90.

[8] Rossignol P, Hernandez AF, Solomon SD, Zannad F. Heart failure drug treatment. Lancet 2019;393:1034-44.

[9] Jansen PM, Danser AH, Imholz BP, van den Meiracker AH. Aldosterone-receptor antagonism in hypertension. J Hypertens 2009;27:680-91.

[10] Menard J. The 45-year story of the development of an anti-aldosterone more specific than spironolactone. Mol Cell Endocrinol 2004;217:45-52.

[11] Parthasarathy HK, Menard J, White WB, Young Jr WF, Williams GH, Williams B, et al. A double-blind, randomized study comparing the antihypertensive effect of eplerenone and spironolactone in patients with hypertension and evidence of primary aldosteronism. J Hypertens 2011;29:980-90.

[12] Achelrod D, Wenzel U, Frey S. Systematic review and meta-analysis of the prevalence of resistant hypertension in treated hypertensive populations. Am J Hypertens 2015;28:355-61.

[13] Cuspidi C, Macca G, Sampieri L, Michev I, Salerno M, Fusi V, et al. High prevalence of cardiac and extracardiac target organ damage in refractory hypertension. J Hypertens 2001;19:2063-70.

[14] Muiesan ML, Salvetti M, Rizzoni D, Paini A, Agabiti-Rosei C, Aggiusti C et al. Resistant hypertension and target organ damage. Hypertens Res 2013;36:485-91.

[15] Daugherty SL, Powers JD, Magid DJ, Tavel HM, Masoudi FA, Margolis KL, et al. Incidence and prognosis of resistant hypertension in hypertensive patients. Circulation 2012;125:1635-42.

[16] Calhoun DA, Jones D, Textor S, Goff DC, Murphy TP, Toto RD, et al. Resistant hypertension: Diagnosis, evaluation, and treatment. A scientific statement from the american heart association professional education committee of the council for high blood pressure research. Hypertension 2008;51:1403-19.

[17] Vongpatanasin W. Resistant hypertension: a review of diagnosis and management. JAMA 2014;311:2216-24.

[18] Hu X, Fan J, Chen S, Yin Y, Zrenner B. The role of continuous positive airway pressure in blood pressure control for patients with obstructive sleep apnea and hypertension: a meta-analysis of randomized controlled trials. J Clin Hypertens (Greenwich) 2015;17:215-22.

[19] Calhoun DA. Hyperaldosteronism as a common cause of resistant hypertension. Annu Rev Med 2013:64:233-47.

[20] Epstein M, Duprez DA. Resistant hypertension and the pivotal role for mineralocorticoid receptor antagonists: a clinical update. Am J Med 2016;129:661-6.

[21] Dahal K, Kunwar S, Rijal J, Alqatahni F, Panta R, Ishak N, et al. The effects of aldosterone antagonists in patients with resistant hypertension: a meta-analysis of randomized and nonrandomized studies. Am J Hypertens 2015;28:1376-85.

[22] Williams B, MacDonald TM, Morant SV, Webb DJ, Sever P, McInnes GT, et al Endocrine and haemodynamic changes in resistant hypertension, and blood pressure responses to spironolactone or amiloride: The pathway-2 mechanisms substudies. Lancet Diabetes Endocrinol 2018;6:464-75.

[23] Krieger EM, Drager LF, Giorgi DMA, Pereira AC, Barreto-Filho JAS, Nogueira AR, et al. Spironolactone versus clonidine as a fourth-drug therapy for resistant hypertension: The rehot randomized study (resistant hypertension optimal treatment). Hypertension 2018;71:681-90.

[24] Pitt B, Kober L, Ponikowski P, Gheorghiade M, Filippatos G, Krum H, et al. Safety and tolerability of the novel non-steroidal mineralocorticoid receptor antagonist bay 94-8862 in patients with chronic heart failure and mild or moderate chronic kidney disease: A randomized, double-blind trial. Eur Heart J 2013;34:2453-63.

[25] McDonald TJ, Oram RA, Vaidya B. Investigating hyperkalaemia in adults. BM] 2015;351:h4762 